\title{
Local governance of safety and the normalization of behavior
}

Stefaan Pleysier

Assistant professor, Leuven Institute of Criminology, Faculty of Law, KU Leuven

H. Hooverplein 10, B-3000 Leuven, Belgium

Tel: +32(0)16325267, E-mail: stefaan.pleysier@law.kuleuven.be

\begin{abstract}
In almost all West-European countries and large parts of the world the governance of public safety tops political priorities at both national and local level. We can observe a growing attention for public safety issues in our cities and streets, resulting in local communities and authorities that increasingly have the possibility to deal with these issues in a rather autonomous way. In this contribution, I discuss the local governance of safety through a critical analysis and reflection of inherent, new regulatory tools within an administrative or civil framework. In doing so, I focus on the precarious position of three specific categories, i.e. minors and youth, panhandlers and 'potential' drug users. This analysis starts off with and draws a parallel to broader social and political trends, which criminologists have described as the shift from a 'post-crime' to a 'precrime' society where pre-emptive logics, mechanisms of exclusion and the criminalization of behavior tend to prevail.
\end{abstract}

\section{Keywords}

Governance, local safety, pre-crime, politics of behavior, criminalization 


\section{Introduction: safety in insecure times}

In almost all West-European countries and large parts of the world, the governance of public safety tops political priorities at both national and local level. The growing attention for public safety issues in our cities and streets seem to adopt the size of a societal quest, even to that extent that several sociologists and criminologists observe a paradigm shift from traditional (penal) welfarism to a risk society or culture of control (Garland 2001; van Swaaningen 2005). Floating on neo-liberal and neo-conservative agendas, this paradigm shift is guided by a new discourse where notions such as 'responsabilization', 'professionalization', 'privatization', 'commercialization', 'efficiency and efficacy', enter the debates and quickly gained amplitude (van Swaaningen 2005; Schuilenburg and van Swaaningen 2013). Under these circumstances and over the last couple of decades, public safety issues have moved from a relatively exclusive task of the police to a mission and shared responsibility of the community at large and a growing number of public-private partnerships (Crawford 2006; van Swaaningen 2005; Pleysier 2008). It is exactly this growing diversification and pluralization of actors and mechanisms of control and surveillance that is generally described as the local 'governance' of public safety (Crawford 2002; 2006; 2011; Schuilenburg 2012).

In this contribution I aim to reflect on and analyze these trends in the local governance of safety and more importantly the emergence of new regulatory tools that differ from a traditional post-hoc criminal justice approach to public safety and crime control. As these trends can be observed in most Western jurisdictions, they do not appear in a sociological vacuum but are to be understood against the backdrop of a diagnosis of our late modern society (Schuilenburg and van Swaaningen 2013).

In what follows, I will therefore start with and draw parallels to broader macrosociological observations that are mirrored in the field of criminology and criminal justice as a shift from a 'post-crime' to a 'pre-crime' society where precaution and pre-emptive logics tend to prevail. As others have already described the relevance of this 'sign of the times' to the debate on crime control and public safety, I limit myself to outline some quintessential aspects of these broader observations as they are pivotal in understanding the debate surrounding the governance of safety and the regulation and normalization of behavior in the public domain.

In the second part of the article, I will illustrate and elaborate on these new regulatory mechanisms and the potential implications on the normalization of behavior in public. In doing so, three specific categories or 'cases' will be reflected upon, i.e. minors and youth, homelessness and panhandling, and 'potential' drug users. The precarious position of these three cases tend to illuminate and sharpen our understanding of the conditions of a pre-crime society and the functioning of pre-emptive politics of behavior. The selection of cases is inspired by and will depart from the local governance of safety and the system of administrative sanctions in Belgium. However, the reflection and analysis based on these cases will surpass the specificity of the Belgian situation and touch upon the broader debate and underlying motivations which are, as mentioned, to a large extent shared and similar in neighboring jurisdictions and other countries.

\section{Risk, pre-crime and precaution}

The above mentioned paradigm shift from a welfare state, focused on the production of prosperity, to a society that is intolerant towards all kinds of uncertainty and insecurity, refers first of all to Ulrich Beck's Risk Society (1992; Crawford 2002; Boutellier 2002). Beck argues that 
our society has entered the phase of a reflexive modernity where the accumulation of knowledge and technology is paralleled by a growing awareness of the production of risks and insecurities. Hence, the modernist project par excellence, the production of order, is losing ground to a defensive culture of control and the management of all sorts of risk.

Life in our late modern risk society is 'both a glorious and a frightening time'; "the system of coordinates in which life and thinking are fastened (...) begins to shake, and a new twilight of opportunities and hazards comes into existence" (Beck 1992: 15; Giddens and Hutton 2000). According to Zygmunt Bauman, we live in a 'liquid' era in which society and individuals within society struggle to balance new freedoms and possibilities on the one hand, and our modern quest for certainty, security and safety, or in German, Sicherheit, on the other hand (Bauman 2000). Boutellier (2002) referred to that balance as the heads and tails of a coin, with 'vitality' on the one hand and 'security' on the other, which can only be combined in a utopian world. The erosion of solid ground and traditional routines and the growing liquidity of all aspects of life and society has promoted the control of risks and the precaution principle as the Leitmotiv of a fearful society.

These macro-sociological observations are mirrored in the field of criminal justice and crime control. In a society characterized by the management and reduction of uncertainty, more than ever the focus will shift towards the registration, archiving, classification and detection of all sorts of risk (Schinkel 2011). The discourse on crime and law enforcement has notably moved from 'crime and punishment' over 'risk and control' to 'uncertainty and precaution' (Boutellier 2011: 66; Pleysier 2014a). In that perspective, Lucia Zedner (2007; 2009) implicitly bridged the international fight against terrorism and the local governance of public safety in our cities and streets. Zedner captured the above mentioned and broad societal trends into the transformation of, as she described, a post-crime society to a pre-crime society. In a pre-crime society law enforcement is no longer based on the transgression of (criminal) law, but on the reduction of insecurity and unsafety, and therefore the early detection and intervention of potential risky behavior. A pre-crime society operates under the precaution principle and aims at the 'governance of the unknowable' (Zedner 2009: 128). The dominant logic is pre-emptive, hence the emergence of new mechanisms of control and surveillance. "Pre-crime (...) shifts the temporal perspective to anticipate and forestall that which has not yet occurred and may never do so" (Zedner 2007: 262).

Following Schuilenburg (2005), I have illustrated the concept of a pre-crime society in previous publications by referring to the science fiction novel and film Minority Report (Pleysier 2012; 2014a). Minority Report was written in 1954 by Philip K. Dick, a notorious science fiction author, and turned into a film by Steven Spielberg in 2002. The plot is set in Washington D.C. anno 2054 where in the past six years not a single murder had been committed: a pre-crime police unit is able to predict and prevent, based on visions of three so-called pre-cogs (i.e. pre-cognition), future crime and murders. According to Schuilenburg (2005), Minority Report is therefore a perfect metaphor for our contemporary system of law enforcement and crime control which is equally guided by precaution and pre-emptive interventions. The film provokes fundamental reflections on human agency and how law enforcement is organized in a society preoccupied with risk and uncertainty. It allows us to see that a pre-crime society has surpassed the idea of risk calculation and exchanged it for the precaution principle which aims at the governance of the unknowable and absolute intolerance towards future and uncertain risks (Zedner 2009: 126; Boutellier 2011). Precaution does not require the possibility to calculate future risks before action is taken, which Zedner illustrates with a striking quote by former US Secretary of Defence Donald Rumsfeld in which he outlines how the war against terrorism in insecure times and uncertain conditions works: "There are known knowns. These are things we know that we know. There are known unknowns. That is to say, there are things that we know we don't know. But there are also unknown unknowns. There are things we don't know we don't know" (Zedner 2009: 126). 
Pre-emptive politics of behavior

It is not that difficult to recognize and transfer the above ideas to the local governance of safety debate. In a pre-crime society the focus of attention will be on registration, detection and control of future risks and (potential) risky behavior of individuals and groups. This trend also tends to pressurize the distinction between repression and prevention (Boutellier 2011). A pre-emptive logic will transform and downsize the traditional idea of prevention to the early detection, intervention and regulation of risky behavior. Willem Schinkel (2011) argues that the emergence of new forms of prevention in fact bends towards the idea of repression. He therefore calls it 'prepression', as "a pro-active repression that attempts the timely suppression of certain forms of life. It attempts the 'adjustment of the present way of life"' (Schinkel 2011: 372). This prepression is not prevention 'as we know it', but the repression of 'risky causal chains' supported by new technologies of registration, archiving and control, and the suppression of alternative 'possible worlds'. Zedner (2009: 74) also mentioned the arrival of new preventive measures that "seek to anticipate and forestall harms long before they occur", in order to maximize security in a proactive manner. Following Schuilenburg (2005) I would like to refer to Minority Report one last time. The prepressive control of crime by the pre-crime unit is grounded on the idea that there is no alternative outcome possible and therefore no 'alternative worlds' exist. In other words, the future offender has no other possibility than to commit the offense. The plot, however, hence the title, is all about the existence of divergent scenarios or 'minority reports' that are silenced and ignored within the pre-crime system because they show the possibility of alternative worlds where a potential murderer does not commit the murder (Schuilenburg 2005: 7; Pleysier 2012). Prepression and the proactive or pre-emptive logic of early detection and intervention has led to a 'politics of behavior' aimed at controlling and regulating undesirable and risky behavior of individuals and groups in the public domain (Crawford 2009a; 2009b; 2011).

\section{New regulatory tools}

In line with the above and parallel to the macro-sociological trends mentioned, we indeed observe the birth of 'new regulatory tools' and initiatives in order to tackle petty crime, public nuisance and antisocial behavior. In most Western countries and jurisdictions local governments and communities have adopted strategies and introduced regulations to tackle threats to the public order and security (Chesnay et al. 2013; van Stokkom 2011; Baillergeau 2014). According to Crawford (2009a) these 'new hybrid tools of regulation' degraded the traditional law and order criminal prosecution from the answer to crime and safety issues to part of a much larger framework of sanctioning and regulation. Much in line with this, Chesnay et al. (2013: 163) use the concept of 'penalization' to refer to the growing tendency to resort to regulatory, civil or administrative law rather than criminal law as "the primary normative punitive system in resolution of conflicts related to the use of public spaces".

In the Netherlands, Bas van Stokkom $(2011 ; 2013)$ reports a growing intolerance towards behavior in public and certain types of incivilities such as ignoring red lights, jumping the queue and drinking beer in parks. This growing intolerance has indeed led to the expansion of legislation and powers to the local police and policy in deploying proactive and reactive strategies of regulating unwanted and undesirable behavior in public. Van Stokkom (2013) followed Crawford (2009a) in labelling these regulatory policies in public space as 'politics of behavior'. Moreover, and mainly in larger cities in the Netherlands, he sees a growing tendency towards offensive practices that are deployed in order to ban and exclude a variety of 'defiant' citizens (beggars, 
homeless people, prostitutes, addicts, loitering youth, etc.) from the public or semi-public domain (van Stokkom 2013; 2011). According to van Stokkom (2011), this outcome is largely the result of pro-active police officers who were in recent years commissioned to issue far more tickets and fines for minor or low level breaches of community regulations or rules. In a number of articles, Schuilenburg explored and analyzed several of these 'exclusionary' practices in the Netherlands, such as the collective shop ban, pub ban and public transport ban. In his view, these practices could indeed be captured under the umbrella of new civil and administrative instruments - 'quasi criminal law' - aimed at regulating access to and behavior in public and semi-public space (Schuilenburg 2009; Wesselink et al. 2009; Schuilenburg and van Steden 2014a; 2014b).

In a similar way, Crawford (2009a; 2009b) describes how antisocial behavior in England and Wales is tackled by so-called ASBO's or Anti-Social Behavior Orders. These orders perfectly fit the above mentioned pre-crime logic in the sense that, according to Crawford (2009a), they exhibit a logic in which antisocial behavior is seen as or serves as a precursor to crime prompting pre-emption and prevention. Inspired by Broken Windows theory, antisocial behavior is seen as a 'first step in a developmental trajectory' for both individuals and communities, and therefore countered by ASBO legislation in order to prevent, at the individual level, 'more serious offending' by 'nipping individual criminal careers in the bud', and at the community level, spirals of decline of disorder, fear and crime (Crawford 2009a: 816). Again, a range of powers or regulatory technologies, significantly expanded in recent years, can be deployed within the ASBO legislation. Although comparable bans to those described in the Netherlands exist, one specific tool that catches the eye is the dispersal power. Crawford (2009a; 2009b) argues that dispersal orders are indicative for the broader pre-emptive and precautionary logic as described above. Apparently, the mere presence of a group of individuals in a designated (dispersal) area can be sufficient to warrant a dispersal order if that presence "is deemed likely to result in a member of the public being 'harassed, intimidated, alarmed or distressed"', even if those individuals have not actually done anything (Crawford 2009a: 823). According to some authors, as governments increasingly fail to capture and resolve larger societal problems, they seem to resort their energy to the 'micromanagement' of public behavior (Crawford 2009a: 814; Schuilenburg and van Steden 2014b).

Since 1999 a federal law in Belgium also offers local communities and authorities the possibility to deal with public safety, nuisance and anti-social behavior in an autonomous way (Cops et al. 2012). Cities and communities are able to draft their own community rules, and enforce and penalize infractions to that code with a system of administrative sanctions. The need to do so was facilitated by at least two elements that stirred both the political debate and public opinion. A first element is the perception or belief that experiences of public nuisance and disorder are related to fear of crime (Devroe 2012). A second element that facilitated the system of administrative sanctions was, much like in the Netherlands, a generally assumed feeling of impunity and a growing intolerance towards petty crime, incivilities and 'undesirable' behavior in the public domain (van Stokkom 2011; Devroe 2012). Legislative changes in January 2014 led to lowering the minimum age from 16 to 14 years old, and expanding the range of possible administrative sanctions. Apart from the traditional fines (up to €350; €175 for minors), communities can also suggest mediation or a community service (up to 30 hours; 15 hours for minors). Furthermore, a specific article offers mayors the possibility to impose a designated public place ban for a period of one month (with the possibility to prolong this period twice) to individuals who disturb public order in specific places.

In the remainder of this contribution, I will depart from the Belgian system of administrative sanction and three specific categories or cases within that system, in order to raise some fundamental and more general questions related to the first part of the article. In doing so, one should bear in mind that compared to e.g. England and Wales or the Netherlands, the system 
of administrative sanctions in Belgium is a relatively 'light' instrument to deal with undesirable behavior in the public domain. Individuals who repeatedly breach local regulations can at most be sanctioned with a new administrative sanction. Breaching an ASBO in England and Wales, which is a civil order, can result in a criminal sanction. Apparently, and according to Crawford, over three fifths of adults and two-fifths of minors who breached their ASBO between 2001 and 2006 were given a custodial sentence (Crawford 2009a: 825).

Although in practice different systems exhibit large divergences, there are undeniably also important parallels and similarities. As was mentioned in the brief description of some countries above, it is clear that "(...) these new regulatory tools muddy the traditional distinctions between civil remedies and criminal sanctions and introduce a form of preventive exclusion that seeks to govern future behaviour rather than regulate past conduct" (Crawford 2011: 502-503; 2009a: 818). Indeed, these new regulatory practices are to a large extent based on the idea and philosophy of Broken Windows theory and the suppression of causal chains, i.e. future criminal careers (Crawford 2009a; van Stokkom 2011; Baillergeau 2014; Chesnay et al. 2013). The precautionary logic and micro-management of behavior in public seems to result in controlling, disciplining and, in the end, the possible exclusion of certain 'risky' individuals and groups from the public domain (Schuilenburg and van Steden 2014b). In what follows, I aim to substantiate and illustrate the above mentioned ideas by elaborating on three specific 'cases', departing from the Belgian system of administrative sanctions, i.e. minors and youth, homelessness and panhandling, and 'potential' drug users. The precarious position of these three specific cases or categories tend to illuminate and sharpen our understanding of the conditions of a pre-crime society and the functioning of pre-emptive politics of behavior.

\section{Three specific cases}

\section{Minors as pre-criminals}

Earlier I mentioned that in Belgium young people from the age of 14 onwards can be subject of an administrative sanction. The lowering of the age limit was to a large extent a symbolic change that elicited discussion and is up to this moment the subject of a case at the Constitutional Court in Belgium. This change has mainly been promoted by a number of mayors from larger cities who pleaded in favor of the possibility to have administrative sanctions for young people from the age of 14 (or even 12) when causing disorder and public nuisance. In a newspaper opinion article, Patrick Janssens, former mayor of the city of Antwerp, argued the necessity to sanction young people below the age of 16 by stating that "those who deem it unjust to expand the system of administrative sanctions to minus 16, should ask themselves what is more unjust: to wait until young people are that derailed that the only place they belong in is a juvenile detention center, or to try to set them back on track, gentle yet firm, at a younger age" (De Morgen 24.01.2012, own translation). The current mayor of Antwerp, Bart De Wever, promoted the lowering of the age limit in a much similar way, stating that "with some youngsters, you need to intervene as young as 12 otherwise things will go wrong" (Het Laatste Nieuws 31.05.2013, own translation). This line of argument surrounding the age limit was recycled in the final draft of the 2014 law that was presented by the former Minister of Interior Joëlle Milquet who stated that lowering the minimum age to 14 is a necessary means to 'prevent a spiral of delinquency' (Pleysier 2013).

The above arguments illustrate how a prepressive approach towards disorder and antisocial behavior is based on the idea that no alternative worlds exist. It promotes a vision where night-time revel and noisy enjoyment, urinating in public space, etc., inevitably will lead to a criminal career unless communities intervene at an early stage to stop this assumed spiral of 
decay and delinquency. This reasoning not only highlights the argument that antisocial behavior needs 'nipping in the bud' in order to prevent worse from happening, it also supports a deterministic approach towards human agency that can be ascribed to the idea of a pre-crime society (Zedner 2009). This recalls an infamous BBC interview with former UK Prime Minister Tony Blair in which he answers to a question on the crime- and prevention policy of the government saying that "there is not going to be a solution [to the problem of youth antisocial behavior] unless we are sufficiently hard-headed to say that from a very early age we need a system of intervention" (Case and Haines 2009: 280). Case and Haines (2009: 295) point in that regard to the possible risks of a system where, often well-intentioned, early intervention strategies intervene in the life of individuals because of a potential and abstract (group) risk or an uncertain future and label those individuals as 'high risk' or 'inevitably pre-criminal'. In a similar manner, Ashworth and Zedner (2012) question to what extent it is justified to intervene at an early stage and criminalize certain behavior in order to prevent uncertain future risks and harms that 'might' be done.

The strategy to early detect and intervene on 'undesirable' behavior is accompanied with and influenced by what Boutellier (2011) has called a 'moral inversion'. The combination of new regulatory tools and a conservative revival has sharpened selective practices of preventative exclusion in the public domain "that seeks to govern future behavior rather than regulate past conduct" (Crawford 2011: 502-503). Building on Goffman's Behaviour in Public Places (1963) and Relations in Public (1971), Dixon et al. (2006) indeed argue that certain practices are classified as incivilities because they can be seen as infractions of the moral order in public life. Hence, conduct becomes 'situationally inappropriate' or 'unacceptable' (Dixon et al. 2006: 188). This element will also return in the discussion on the second case or illustration. In England and Wales, Crawford has illustrated this by referring to the emergence of a number of wide-ranging restrictions such as designated public places orders, dispersal powers, drinking bans, etc. (Crawford 2009a; 2009b; 2011). Schuilenburg mentioned similar mechanisms by using the concept of 'selective exclusion' in the Netherlands (Schuilenburg 2012). In the margin of the new legislation on administrative sanctions in Belgium, I referred in the above to a new power to the mayor to impose designated public place bans to individuals who disturb public order in specific places. Several cities and communities also have a public drinking ban that disallows drinking alcohol in a designated area which can be enforced by an administrative sanction. Although these pre-emptive regulations of 'undesirable' behavior are not necessarily specifically aimed at young people, in their consequence these restrictions and bans further hypothecated the position of certain societal groups, such as young people, in public space (Crawford 2009a; 2009b).

\section{Homelessness and panhandling in sterile city centers}

As in several other countries, Belgium abolished in 1993 an old criminal law that penalized panhandling and vagabondage. Although aggressive solicitation and exploiting people to panhandle is still punishable by criminal law, several propositions to reintroduce a ban on panhandling as such have been discussed in parliament. Based on that abolition, one could conclude that there is a de facto right to beg, seek alms and appeal on others' solidarity. What we see, however, is that cities and communities try to recover the abolished ban using the system of administrative sanctions by stipulating in their police or community codex that panhandling is forbidden in a specific perimeter or designated area of the city or community. Local authorities defend this ban by referring to the supposed fact that panhandling is often a pretext for pickpocketing and shoplifting, which feeds the above mentioned idea that in order to prevent theft one has to intervene on the 'antecedent' behavior, i.e. panhandling. 
These local bans still exist in different communities, although the Council of State in Belgium has in a recent past recalled different communities that have tried banning panhandling in their city center using similar codes and likewise arguments. As one can still penalize aggressive panhandling, pickpocketing or shoplifting by using criminal law, the arguments of local authorities are not fully waterproof. Furthermore, it might be considered somewhat strange and even short-sighted to tackle panhandling by giving beggars a fine. Local authorities, however, do have a responsibility to maintain public order and safety in their community, which inspired several communities to add the adjective 'aggressive' or 'obtrusive' to the concerning article in their codex.

The question is whether (obtrusive) panhandling is indeed tackled by those authorities because of the threat it poses to public order and local safety. If that would be the case, one could wonder why the undesirable behavior of panhandling is seemingly only undesirable and unwanted in specific designated areas in the city. This reflects the above mentioned idea of Dixon et al. (2006: 188-189) that conduct and behavior in public space is defined as 'situationally inappropriate' based on 'normative definitions' of place. Behavior is defined as problematic and deemed punishable not because of the behavior in se, but because it is 'out of place' (Dixon et al. 2006; van Stokkom 2013; Margier et al. 2014). In most cases this perimeter of the ban on panhandling is situated around the commercial city center and shopping streets. In their study on homeless people in Canada, Chesnay et al. (2013) point to the fact that the visibility of homelessness urged cities to reaffirm the city center as 'focused on consumption, leisure, and luxury'. As such, the behavior of homeless people, but also loitering young people, could be considered 'out of place': it violates "the consumerist norms that regulate public life in such spaces" (Dixon et al. 2006: 190).

In fact, this reasoning brings us back to Bauman (1997) and what he has described as 'the dream of purity'. According to Bauman, who is here inspired by Douglas Purity and Danger (1966), parallel to our modern urge for (a vision of) order we dream of purity: "purity is a vision of things put in places" (Bauman 1997: 6). Furthermore, the opposite of purity ('dirt') or order are then things 'out of place'. The idea of 'situationally inappropriate' behavior (Dixon et al. 2006), returns when Bauman (1997: 6) states that it "is not the intrinsic quality of things which makes them into 'dirt', but solely their location; more precisely, their location in the order of things envisaged by the purity-seekers". The commercial hearts of our cities are increasingly designed to be sterile, zero friction places, aimed at leisure and consummation, and with as little distraction away from that aim as possible (van Stokkom 2013; Schuilenburg and van Steden 2014a; Crawford 2011). In these sanitized public spaces, homeless people and beggars are 'out of place', they are 'unappetizing' 'polluting agents' (Bauman 1997: 6; van Stokkom 2013; Margier et al. 2014).

It is in that respect perhaps also indicative that in some cities in Belgium, based on the code of administrative sanctions, it is seemingly considered as an aggravated circumstance if one panhandles 'by using animals', or 'generates charity from people in the streets by exposing one's handicap, bodily disfiguration, mutilation or injuries'. This strategy not only points to mechanisms of selective exclusion or banning of impure and undesirable individuals from certain parts of the city, it also stigmatizes and criminalizes homeless people and beggars because of their 'otherness'. This process of 'othering' and the exclusive mechanisms in our society are closely interrelated: "there are imaginary geographies which place imperfect minorities in marginalised locations: in a social elsewhere" (Ruggiero 2000: 1, quoted in Goodey 2002: 135). Elsewhere, I illustrated the above with a reference to Les yeux des pauvres ('The eyes of the poor'), a within urban sociology well-known poem by Charles Baudelaire (Pleysier 2014b). In this poem, Baudelaire and his company close a romantic night in a café at one of Paris' beautiful boulevards. The perfect night out, until they are 'disturbed' by the hungry eyes of a threesome dressed in rags. Baudelaire is 
touched by that family of eyes, and feels ashamed 'of our glasses and our carafes, much larger than our thirst', but all the more because of the reaction of his love when she said to him: 'I can't stand those people over there, with their eyes wide open like carriage gates! Can't you tell the headwaiter to send them away?'.

Looking for drugs and the regulation of intentions

A final case or illustration I wish to elaborate on in this contribution departs from a particular article in the police codex of the city of Antwerp. This article states that it is forbidden to frequent the public domain with the aim of purchasing illegal drugs, what is further deduced in e.g. the prohibition of behavioural proceedings that cause public nuisance and that are related to the search for drug dealers or go-betweens in the purchase or consumption of illegal drugs. These 'behavioural proceedings' are subsequently defined as 'hanging about in streets, squares, parks or places adjacent to the public space, etc.' (Flamand 2011). Flamand indicates that, given the fact that local authorities are not allowed to adopt legislation that can be penalized at a higher level, the specific article is not targeted towards infringements against criminal law, but is in fact an article on 'drugs-related or intended nuisance'. This raises however important questions, since it de facto penalizes 'intentions': civil servants who register infractions will have to be able to 'look inside the head' and sense the motives and intentions of those who behave in public in a certain way. In doing so, local authorities trespass the unauthorized domain of the 'moral public order' where the system of administrative sanctions is by law confined to the domain of 'material public order' (Flamand 2011: 11).

This particular case exemplifies a broader issue that has already been raised at least implicitly in the above. Based on a study on urban intervention teams in Rotterdam, the Netherlands, Schuilenburg $(2009 ; 2012)$ observes a 'new interference' or meddling in the social life of civilians that can be ascribed to a renewed paternalism or re-moralization of our contemporary society (see also Boutellier 2011; Margier et al. 2014). As was the case with homelessness and panhandling, public safety and order could to some extent be seen as a 'sophist' reason to tackle welfare and care issues. Schuilenburg (2009) mentions how, in a pre-crime society focusing on early detection and intervention, there is a thin line between health and welfare on the one hand, and crime, security and safety on the other hand. Witnessing a paradigm shift from a traditional welfarist approach to a risk society and culture of control has to a certain extent indeed instrumentalized questions of care and wellbeing into a framework focused on the early detection and intervention of all sorts of risk. In that respect, 'nuisance policing' contributes to the 'invisibilization of social problems' (Baillergeau 2014: 5).

With a final reference to the Belgian practice of administrative sanctions, we can see that some cities indeed developed and cultivated a practice where the administrative fine is used as a lever or big stick to motivate individuals into a community service, intervention or program. Based on similar observations in the Netherlands, Schuilenburg (2009: 17) refers to the concept of 'outreaching', as a combination of care and control, borrowed from the field of social work. In a similar way actors within the above mentioned regulatory tools and practices use what they call 'assertive outreach' as a prepressive and normative approach to what are in essence social problems (Pleysier 2013). 


\section{Conclusion}

Departing from three specific 'cases', the aim of this article was to reflect upon recent trends in the local governance of safety and the emergence of new regulatory tools. The cases served as illustrations, and although I do not wish to deny obvious differences across and within countries and jurisdictions, they lead to a number of reflections and conclusions that surpass both the level of the particular cases and the Belgian context in which they are situated. First, they could be considered as indicative for the broader macro-sociological observations and more in particular the observed trends in the field of crime control and the governance of safety. In line with others, this was summed up in a shift from a 'post-crime' to a 'pre-crime' society where precaution and pre-emptive logics assume a pivotal position (Zedner 2007; 2009). Hence, behavior in the public domain is increasingly labelled as 'antisocial', 'risky', and even 'pre-criminal'. It is a precursor of a criminal career and needs therefore 'nipping in the bud' (Crawford 2009a). In doing so, Crawford (2009b) argues that even the mere presence of (groups of) youngsters in public spaces can be seen as problematic, and normal activities and youth sociability are at risk of becoming criminalized.

Secondly, the case or illustration surrounding homelessness and panhandling in the city center pointed to a next layer in the above conclusion. Based on this debate, it becomes clear that crime and safety seemingly are convenient pretenses to control and exclude certain (groups of) 'undesirable' individuals from (certain parts of) the public domain. The exclusion of these groups is not in the first place based on their threat to the public order and safety, but in the fact that they seem to violate unspoken 'consumerist norms that regulate public life' in the city center (Dixon et al. 2006; Crawford 2011). Their 'otherness' disrupts the 'orderliness' of the sterile city center focused on leisure and consumption. As Bauman stated, in a society of consumers, "flawed consumers are its most irksome and costly liabilities" (Bauman 2004: 39). Also, the pre-emptive exclusion of these undesirable and 'irksome' should be done in an aesthetically pleasing and consumer-friendly way (Crawford 2011: 495). These observations, according to Crawford (2011: 483), point to a dynamic of exclusion that was previously confined to private and semi-public places, as the shopping mall, and is now gradually extending to the public realm. Apart from blurring boundaries between public and private, this also points to the ambiguous relationship "between inclusion and exclusion on the one hand and commercial imperatives and security demands on the other" (Crawford 2011: 512).

The third and final illustration sums up both above mentioned conclusions in melting together the pre-emptive logic of crime control and the exclusion of the 'undesirable'. The particular case exemplified strategies of early detection and intervention based on controlling motives and intentions (to buy or use illegal drugs). Much in line with the above and somewhat more in general, it points to the adoption of a 'law and order' discourse as a passe-partout to tackle and intervene in welfare and health issues. In their study in Rotterdam, Schinkel and van den Berg (2011: 1932) reported similar practices mixing prevention and assistance, and repression and control into an 'ensemble of techniques of governmentality' targeting specific urban subpopulations. Again, a blurring boundary is central, this time between health and welfare on the one hand, and crime, security and safety on the other hand (Schuilenburg 2009).

Although we must be careful not to oversimplify or exaggerate the impact or generality of the observations and reflections raised in this contribution, the conclusion that we indeed seem to witness the emergence of new regulatory practices and pre-emptive mechanisms of control and normalization of behavior, is indeed not too farfetched. Moreover, these regulatory tools and practices tend to focus on the most vulnerable groups in our society. As such, it seems justified to broaden Crawford's conclusion in his study on the criminalization of young people to other vulnerable groups in society to whom we not only tell that they are "not welcome in certain 
essential public places" but also convey "stark messages about their status and value in society more generally” (Crawford 2011: 513; 2009b: 22-23). 


\section{References}

Ashworth, A., \& Zedner, L. (2012), Prevention and criminalization: justifications and limits, New Criminal Law Review, 15(4), 542-571.

Baillergeau, E. (2014), Governing public nuisance: collaboration and conflict regarding the presence of homeless people in public spaces of Montreal, Critical Social Policy, Published online before print April 1, 2014, doi: 10.1177/0261018314527716.

Bauman, Z. (1997), Postmodernity and Its Discontents, Cambridge: Polity Press.

Bauman, Z. (2000), Liquid modernity, Cambridge: Polity Press.

Bauman, Z. (2004). Wasted lives. Cambridge: Polity Press.

Beck, U. (1992). Risk Society. Towards a New Modernity. London: Sage.

Boutellier, H. (2002), De Veiligheidsutopie. Den Haag: Boom Juridische Uitgevers.

Boutellier, H. (2011), De improvisatiemaatschappij. Over de sociale ordening van een onbegrensde wereld, Den Haag: Boom Lemma.

Case, S., \& Haines, K. (2009), Understanding Youth Offending. Risk factor research, policy and practice. Devon: Willan Publishing.

Chesnay, C.T., Bellot, C., \& Sylvestre, M.-E. (2013), Taming disorderly people one ticket at a time: the penalization of homelessness in Ontario and British Columbia, Canadian Journal of Criminology and Criminal Justice, 55(2), 161-185.

Cops, D., Put, J., \& Pleysier, S. (2012), De GAS-wetgeving als instrument voor de aanpak van overlast. Bedenkingen bij en suggesties voor een integraal en onderbouwd overlastbeleid. Panopticon, 33(6), 552-563.

Crawford , A. (ed.)(2002), Crime and Insecurity. The governance of safety in Europe. Cullompton, Devon: Willan Publishing.

Crawford, A. (2006), Networked governance and the post-regulatory state? Steering, rowing and anchoring the provision of policing and security, Theoretical Criminology, 10(4), 449-479.

Crawford, A. (2009a), Governing through anti-social behaviour. Regulatory Challenges to Criminal Justice. British Journal of Criminology, 49, 810-831.

Crawford, A. (2009b), Criminalizing sociability through anti-social behaviour legislation: dispersal powers, young people and the police. Youth Justice, 9(1), 5-26.

Crawford, A. (2011), From the shopping mall to the street corner: dynamics of exclusion in the governance of public space. In A. Crawford (Ed.), International and comparative criminal justice and urban governance (pp. 483-518). Cambridge: Cambridge University Press.

Devroe, E. (2012), A Swelling Culture of Control? De genese en toepassing van de wet op de gemeentelijke administratieve sancties in België. Antwerpen: Maklu.

Dixon, J., Levine, M., \& McAuley, R. (2006), Locating Impropriety: Street Drinking, Moral Order, and the Ideological Dilemma of Public Space, Political Psychology, 27(2), 187-206. 
Douglas, M. (1966), Purity and Danger, an Analysis of Concepts of Pollution and Taboo, New York: Frederick A. Praeger.

Flamand, E. (2011), Verboden rond te hangen met slechte bedoelingen, De Juristenkrant, April, 11.

Garland, D. (2001), The Culture of Control. Crime and Social Order in Contemporary Society. Oxford: Oxford University Press.

Giddens, A. \& Hutton, W. (2000), Fighting back. In W. Hutton \& A. Giddens (Eds.), On the Edge. Living with Global Capitalism (pp. 213-224). London: Jonathan Cape.

Goffman, E. (1971), Relations in Public. Microstudies of the Public Order, New York: Basic Books.

Goffman, E. (1963), Behavior in Public Places. Notes on the Social Organization of Gatherings, New York: Free Press.

Goodey, J. (2002). Whose insecurity? Organised crime, its victims and the EU. In A. Crawford (Ed.). Crime and Insecurity. The governance of safety in Europe (pp. 135-158). Cullompton: Willan Publishing.

Margier, A., Bellot, C. \& Morin, R. (2014). L'itinérance en milieu urbain. Deux voies de normalisation. Le sociographe, 48, 21-32.

Pleysier, S. (2008), 'Integrale veiligheid' als dogma? Grenzen aan het heersende veiligheidsdiscours, Tijdschrift voor Veiligheid, 7(1), 34-46.

Pleysier, S. (2012), Kind als gevaar. De nieuwe preventie en criminalisering van gedrag. Tijdschrift voor Jeugd en Kinderrechten, 4, 278-288.

Pleysier, S. (2013), GAS als 'sluitstuk', GAS als 'hefboom' (Book review of Devroe, E. (2012). A Swelling Culture of Control? De genese en toepassing van de wet op de gemeentelijke administratieve sancties in België), Cahiers Politiestudies, 29(4), 339-344.

Pleysier, S. (2014a), Emancipatorische preventie: weerstaan aan de lokroep van pre-pressie. In Burssens D., Goris P., Melis B., \& Vettenburg N. (Eds.), Preventie morgen. Bouwstenen voor een goede praktijk (pp. 33-40). Antwerpen: Garant.

Pleysier, S. (2014b), Verboden te bedelen in de steriele stad, Knack Online (http://www.knack.be/nieuws/belgie/bedelaars-zijn-niet-welkom-in-de-smetvrije-binnenstaddie-is-er-voor-consumptie-en-vermaak/article-opinion-274341.html).

Schinkel, W. (2011), Prepression: The actuarial archive and new technologies of security, Theoretical Criminology, 15(4), 365-380.

Schinkel, W., \& van den Berg, M. (2011), City of exception: the Dutch revanchist city and the urban Homo Sacer. Antipode, 43(5), 1911-1938.

Schuilenburg, M. (2005), Voorwoord bij 'De verbeelding van misdaad en straf', Justitiële Verkenningen, 31 (4), 5-10.

Schuilenburg, M. (2009), De securisering van de samenleving. Over de relatie tussen veiligheidszorg, bestuur en quasistrafrecht, Krisis. Tijdschrift voor actuele filosofie, 3, 6-22.

Schuilenburg, M. (2012), Orde in veiligheid. Een dynamisch perspectief, Den Haag: Boom Lemma uitgevers.

Schuilenburg, M., \& van Swaaningen, R. (2013), Veiligheid in een laatmoderne cultuur, Tijdschrift over Cultuur \& Criminaliteit, 3(2), 109-122. 
Schuilenburg, M. \& van Steden, R. (2014a), Praktijken van selectieve uitsluiting. Over de bescherming door en tegen veiligheidsassemblages, Cahiers Politiestudies, 30(1), 51-62.

Schuilenburg, M. \& van Steden, R. (2014b). De collectieve Horeca Ontzegging: uitsluiting uit de publieke ruimte?, Beleid en Maatschappij, 41(1), 4-18.

van Stokkom, B. (2011), Dealing with defiant citizens: Building emotional intelligence into police work. In: S. Karstedt, I. Loader, \& H. Strang (Eds.), Emotions, Crime and Justice (pp. 235-254). London: Hart Publishing.

van Stokkom, B. (2013), Onveiligheid als stedelijkheidsfobie. Angst en onmacht in de hygiënische stad, Tijdschrift over Cultuur \& Criminaliteit, 3(2), 137-154.

van Swaaningen, R. (2005), Public safety and the management of fear, Theoretical Criminology, 9(3), 289-305.

Wesselink, L., Schuilenburg, M., \& Van Calster, P. (2009), De Collectieve Winkelontzegging, Tijdschrift voor Veiligheid, 8(1), 6-19.

Zedner, L. (2007), Pre-crime and post-criminology?, Theoretical Criminology, 11(2), 261-281.

Zedner, L. (2009), Security. Key Ideas in Criminology. London: Routledge. 